\title{
Author's Reply; Nucleic Acid Testing for the Detection of HBV DNA
}

\author{
Mohammad Kazemi Arababadi 1,2* \\ ${ }^{1}$ Department of Microbiology, Hematology and Immunology, Faculty of Medicine, Rafsanjan University of Medical Sciences, Rafsanjan, IR Iran \\ ${ }^{2}$ Infectious and Tropical Diseases Research Center, Rafsanjan University of Medical Sciences, Rafsanjan, IR Iran
}

\begin{tabular}{l}
\hline A R T I C L E I N F O \\
\hline Article type: \\
Letter to Editor \\
\hline Article history: \\
Received: 07 Sep 2011 \\
Revised: 22 Sep 2011 \\
Accepted: 25 Sep 2011 \\
\hline
\end{tabular}

Keywords:

Nucleic Acids

Hepatitis B

\section{Dear Editor,}

First, we agree with Seto et al. regarding the impacts of the sensitivity of the detection methods of OBI (occult hepatitis B infection) prevalence but disagree regarding their idea on the lack of usefulness of anti-HBc screens. They have referred to Seo et al., who reported that the prevalence of anti-HBc positivity in Korea was 13.5\%, whereas the prevalence of OBI was $0.016 \%$ (1). Anti-HBc is the first antibody that is produced against HBV and is the most stable antibody (2); hence, the presence of the antibody in individuals demonstrates introduction of HBV to the immune system via several mechanisms, including transfusion $(3,4)$. Therefore, it seems that the rate of OBI among anti-HBc-positive persons is more than the anti-HBc-negative blood donors (5). During blood screening programs, hepatitis B surface antigen (HBsAg) testing, followed by polymerase chain reaction (PCR) assays, will be the most accurate approach of identifying OBI, but some blood transfusion services are unable to use PCR (based on high costs). We have proposed applying anti-HBc as a screening test for blood transfusion services that are unable to use PCR to reduce the risk of PTH

* Corresponding author at: Mohammad Kazemi Arababadi, Department of Microbiology, Hematology and Immunology, Faculty of Medicine, Rafsanjan University of Medical Sciences, Rafsanjan, IR Iran. Tel: +98-39152340035, Fax:+98-3915225209. E-mail: dr.kazemi@rums.ac.ir

DOI: 10.5812/kowsar.1735143X.758

Copyright @2011, BRCGL, Published by Kowsar M.P.Co. All rights reserved.
Please cite this paper as:

Arababadi MK. Author's Reply; Nucleic Acid Testing for the Detection of HBV DNA. Hepat Mon. 2011;11(10):849. DOI: 10.5812/ kowsar.1735143X.758

๑ 2011 Kowsar M.P.Co. All rights reserved.

via OBI-infected blood and its components.

Second, Seto et al. have presented a nice mechanism for the possible cause for cryptogenic HCC in endemic chronic hepatitis B regions. They have described a good, probable mechanism of undetectable virological HBV markers in tumor histology. These mechanisms should be examined in future studies.

\section{References}

1. Seo DH, Whang DH, Song EY, Kim HS, Park Q. Prevalence of antibodies to hepatitis B core antigen and occult hepatitis $B$ virus infections in Korean blood donors. Transfusion. 2011;51(8):1840-6.

2. Arababadi MK, Pourfathollah AA, Jafarzadeh AA, Hassanshahi G. Serum levels of Interleukin (IL)-10 and IL-17A in occult HBV infected south-east Iranian patients. Hepat Mon. 2010;10(1):31-5.

3. Stolz M, Tinguely C, Graziani M, Fontana S, Gowland P, Buser A, et al. Efficacy of individual nucleic acid amplification testing in reducing the risk of transfusion-transmitted hepatitis B virus infection in Switzerland, a low-endemic region. Transfusion. 2010;50(12):2695-706.

4. Chotiyaputta W, Pelletier SJ, Fontana RJ, Lok AS. Long-term efficacy of nucleoside monotherapy in preventing HBV infection in HBsAg-negative recipients of anti-HBc-positive donor livers. Hepatol Int. 2011;4(4):707-15.

5. Arababadi MK, Pourfathollah AA, Jafarzadeh A, Hassanshahi G, Rezvani ME. Association of exon 9 but not intron 8 VDR polymorphisms with occult HBV infection in south-eastern Iranian patients. J Gastroenterol Hepatol. 2009;25(1):90-3. 